\title{
Urinary tissue factor in glomerulonephritis: a potential marker of glomerular injury?
}

\author{
B A Lwaleed, P S Bass, M Chisholm, J L Francis
}

\begin{abstract}
Aim-To investigate the significance of urinary tissue factor (uTF) concentrations in patients with glomerulonephritis. Methods-Urine samples were collected from normal subjects $(n=57)$, patients with uncomplicated renal stones $(n=30)$, and patients with glomerulonephritis $(n=150)$. Samples were then centrifuged and the pellets solubilised in $n$-octyl- $\beta$ glucopyranoside. uTF concentrations were determined using a one stage kinetic chromogenic assay.
\end{abstract}

Results-The uTF concentration was higher in patients with glomerulonephritis than in normal controls $(p<0.01)$ or in patients with renal stones $(p<0.05)$. uTF activity correlated with the protein creatinine index (PCI, $r=0.41, \mathrm{p}<0.001$ ) and seven patients with glomerulonephritis and a PCI $\leqslant 0.1 \mathrm{~g} / \mathrm{mmol}$ had raised uTF. Glomerulonephritis patients were subdivided into two groups depending on the PCI: $<0.2 \mathrm{~g} / \mathrm{mmol}$ creatinine (mild to moderate proteinuria, group I) and $\geqslant 0.2 \mathrm{~g} / \mathrm{mmol}$ creatinine (heavy proteinuria, group II). In group I, UTF concentrations were higher in patients with either immune complex (IC) glomerulonephritis $(p<0.01)$ or non-IC $(p<0.05)$ glomerulonephritis than in normal controls. In group II, the IC glomerulonephritis group had higher uTF concentrations than normal controls $(p<0.001)$ or patients with renal stones $(p<0.01)$; and non-IC glomerulonephritis patients had higher uTF than normal controls $(p<0.01)$. When the glomerulonephritis groups were divided into broad WHO subtypes, the significance level varied with the type of glomerulonephritis.

Conclusions-uTF is increased in patients with glomerulonephritis, and its concentration may reflect the aetiopathogenesis of glomerulonephritis.

$(\Im$ Clin Pathol 1997;50:336-340)

Keywords: urinary tissue factor; monocyte/macrophage tissue factor; coagulopathy; glomerulonephritis

Activation of blood coagulation and fibrin deposition are associated with various forms of inflammatory glomerular diseases in humans and laboratory animals. ${ }^{1-3}$ Fibrin deposition within and around the glomerulus has been observed by several investigators ${ }^{45}$ and is thought to play a major role in the development and the progression of some forms of glomerular disease. ${ }^{6-9}$ The underlying biological mechanism of such phenomena remains poorly understood. However, it has been suggested that the source of glomerular procoagulant activity could either be bloodborne or generated by resident glomerular cells. Glomerular fibrin deposition is dependent on leucocyte accumulation, ${ }^{10}$ and rabbits treated with mustine hydrochloride develop severe leucopenia, which prevents glomerular macrophage accumulation and glomerular fibrin deposition without any functional alteration of the host coagulation factors. ${ }^{10}$ Mononuclear cells are known to be a potent source of procoagulant activity. ${ }^{11}{ }^{12}$ Increased expression of procoagulant activity by monocytes/macrophages in several inflammatory conditions, particularly after stimulation with Escherichia coli endotoxin, is well documented. ${ }^{11}{ }^{13-15}$ Similarly, isolated human and animal glomeruli with different forms of glomerular disease express high levels of procoagulant activity. ${ }^{216-18}$ Further evidence of the involvement of mononuclear and intrinsic glomerular cells can be drawn from tissue culture studies of isolated glomeruli where both cell types have been shown to express increased levels of procoagulant activity. ${ }^{210}$ However, fibrin deposition in the kidney may also result from impaired activity of the fibrinolytic system. ${ }^{17}$

Initially, renal procoagulant activity was thought to activate the extrinsic pathway of the coagulation cascade by at least three different mechanisms. ${ }^{19-21}$ However, it has recently been shown that blood coagulation can only proceed through a tissue factor dependent pathway. ${ }^{21}$ This is supported by the findings of Hoyer et al who excluded the involvement of factor VIII in glomerular fibrin deposition, ${ }^{22}$ and the correlation between tissue factor from glomerular supernatants and thromboxane B2 (TxB2) formation in platelets. ${ }^{23}$ Tissue factor apoprotein is a $46 \mathrm{kDA}$, single chain, integral plasma membrane glycoprotein with no intrinsic protease activity. ${ }^{24}$ Tissue factor serves as a receptor and essential cofactor for the serine protease blood coagulation factors VII and VIIa $^{26}$ in the activation of factors $\mathrm{X}$ and IX-thus it is an important initiator of blood coagulation. ${ }^{27}$ Tissue factor is not only found on mononuclear cells or in lysed isolated glomeruli but also in a lipid associated form in the urine (uTF), ${ }^{28}$ where its concentration may be of clinical significance, particularly in patients with inflammatory diseases and neoplasia. ${ }^{29-35}$ Indeed, uTF concentrations were found to be increased in patients with malignant diseases compared with patients with corresponding benign diseases and with normal controls, but not compared with patients with inflammatory diseases. ${ }^{33-35}$ Analysis of UTF in pathological renal states has until 
recently been limited to animal models, with rather conflicting results. ${ }^{17}$ Recently, we have developed a highly standardised assay for uTF measurement (to be published). In this preliminary study, we applied this assay to patients with glomerulonephritis and examined the hypothesis that $\mathrm{uTF}$ concentrations may reflect the pathogenesis of glomerular damage or its degree.

\section{Methods}

PATIENTS

Ethics committee approval was obtained for the study and informed consent was sought from each patient on arrival at the outpatient clinic at the Royal South Hants Hospital, Southampton, during 1993 to 1994. All patients included in the study had biopsy proven renal disease (biopsies performed between 1990 and 1994). The biopsy reports were retrieved and classification of glomerulonephritis was made according to the criteria of the Collaborating Centre for the Histological Classification of Renal Diseases of the WHO. ${ }^{36}$ Urine was collected from 237 subjects: controls (healthy volunteers $(n=57)$ and patients with "uncomplicated" renal stones and a normal erythrocyte sedimentation rate $(n=30))$, and patients with glomerulonephritis $(n=150)$. The glomerulonephritis group was made up of minor glomerular abnormalities $(n=4)$; diffuse glomerulopathy (type I membrano-proliferative glomerulonephritis $(\mathrm{n}=11)$, mesangio-proliferative glomerulonephritis ( $n=33$ ), and membranous glomerulonephritis $(n=19)$ ); focal segmental proliferative glomerulonephritis $(n=26)$; focal segmental glomerulosclerosis $(n=20)$; and miscellaneous diseases $(n=37)$. The latter group included patients with diabetes, amyloid, and ischaemic changes. All patients on steroids at the time of urine collection were excluded from the study, as were patients with crescentic glomerulonephritis.

\section{UTF MEASUREMENT}

Urine samples were collected from each subject into sterile universal containers without preservative. Samples were then sedimented, solubilised, and assayed. Briefly, the extracted uTF, in the presence of recombinant factor VIIa (rVIIa) and $\mathrm{Ca}^{2+}$, forms a complex (tissue factor $/ \mathrm{rVII} / \mathrm{Ca}^{2+}$ ) which then directly activates factor $\mathrm{X}$ to factor $\mathrm{Xa}$. Generation of factor $\mathrm{Xa}$, which is proportional to the amount of tissue factor in the urine sample, was determined by measuring its action on a factor $\mathrm{Xa}$ specific chromogenic substrate. The rate of the reaction at $405 \mathrm{nM}$ was determined in a Biokinetics EL-312e microplate reader (Bio Tek Instruments, Winooski, Vermont, USA), programmed to read the absorbance at 30 second intervals over a period of 35 minutes. Absorbance values were converted to tissue factor (ng) $\mathrm{ml}$ ) using a calibration curve constructed from serial dilutions of recombinant relipidated tissue factor (rrTF, $0.4-83 \mathrm{ng} / \mathrm{ml}$ ) prepared according to Carson and Konigsberg ${ }^{37}$ in BOG ( $\beta$-octyl-glucopyranoside, Sigma, Poole, Dor- set). For maximum accuracy the calibration standards were measured in each plate.

EXPRESSION OF UTF RESULTS

The results (ng/ml) were corrected for the dilution of the urine using the creatinine concentration of the sample. Final results were expressed as $\mathrm{uTF} \mathrm{ng} / \mathrm{ml}$ per $\mathrm{mg}$ creatinine: $\mathrm{uTF}(\mathrm{ng} / \mathrm{ml}) /$ creatinine $(\mathrm{mg} / \mathrm{dl}) \times 100$.

PROTEIN CREATININE INDEX MEASUREMENTS

Total protein and creatinine were measured according to the standard $\mathrm{CX} 7$ protocol automated analyser (Beckman, Brea, California, USA). The protein creatinine index (PCI) was then calculated as: total protein $(\mathrm{g} / \mathrm{l}) /$ creatinine $(\mathrm{g} / \mathrm{mmol}){ }^{38} 39$

\section{STATISTICAL ANALYSIS}

Data were included in a database and analysed by the Statgraphics statistical software system. Data were not normally distributed, and summary statistics were expressed as medians and interquartile ranges (IQR). Differences between two groups were assessed by the MannWhitney U test.

\section{Results}

There was a significant difference in $\mathrm{UTF}$ concentrations between patients with glomerulonephritis and normal controls $(\mathrm{p}<0.01)$ and patients with renal stones $(p<0.05$, fig 1 ) $54.9 \%$ of patients with glomerulonephritis showed a uTF level above the upper quartile of the normal controls, in contrast to $36.7 \%$ in the renal stones group. There was a weak correlation between $\mathrm{uTF}$ and PCI values $(r=0.41$, $\mathrm{p}<0.001)$. The glomerulonephritis group was then subdivided according to the PCI level at the time of the biopsy. Group I had a PCI of $<0.2 \mathrm{~g} / \mathrm{mmol}$ (that is, less than about $2 \mathrm{~g} /$ day, mild to moderate proteinuria), and group II $\geq 0.2 \mathrm{~g} / \mathrm{mmol}$ (heavy proteinuria). In addition, two broad groups of glomerulonephritis patients were distinguished-namely immune complex (IC) glomerulonephritis (type I membrano-proliferative glomerulonephritis, mesangio-proliferative glomerulonephritis, and membranous glomerulonephritis) and non-IC glomerulonephritis (minor glomerular abnormalities and focal segmental glomerulosclerosis). In group I (low PCI), the IC group $(p<0.01)$ and the non-IC group $(p<0.05)$ both had higher uTF values than the normal controls, but not than the renal stones group. In group II (high $\mathrm{PCI}$ ), the IC glomerulonephritis group $(p<0.001)$ and the non-IC glomerulonephritis group $(p<0.01)$ also had higher UTF values than the normal controls, and a significant difference was observed between the renal stones group and the IC glomerulonephritis group as well $(\mathrm{p}<0.01$, fig $2 \mathrm{~A}$ and $2 \mathrm{~B}$ ).

In group I, no significant difference was found between the IC and the non-IC groups; in group II, the IC glomerulonephritis group had a higher, but wider, range of uTF values ( 8 to 29) compared with the non-IC glomerulonephritis group (7 to 16), but the difference was not significant (fig $3 \mathrm{~A}$ and $3 \mathrm{~B}$ ). There was 


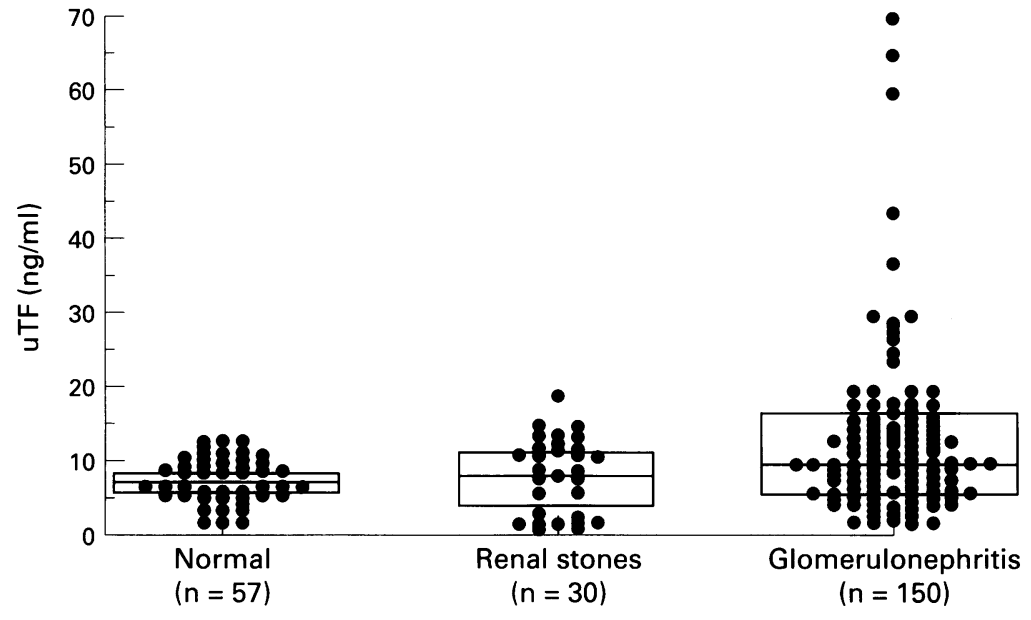

Figure 1 Urinary tissue factor (uTF) concentrations in control groups and patients with glomerulonephritis. Results are shown as median and the interquartile ranges.

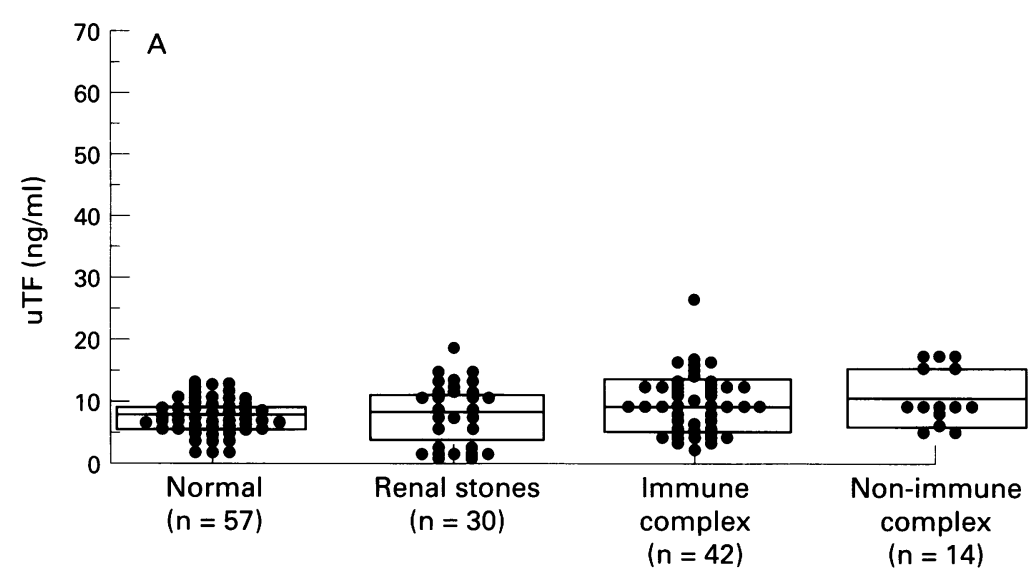

$\mathrm{PCl}<0.2 \mathrm{~g} / \mathrm{mmol}$

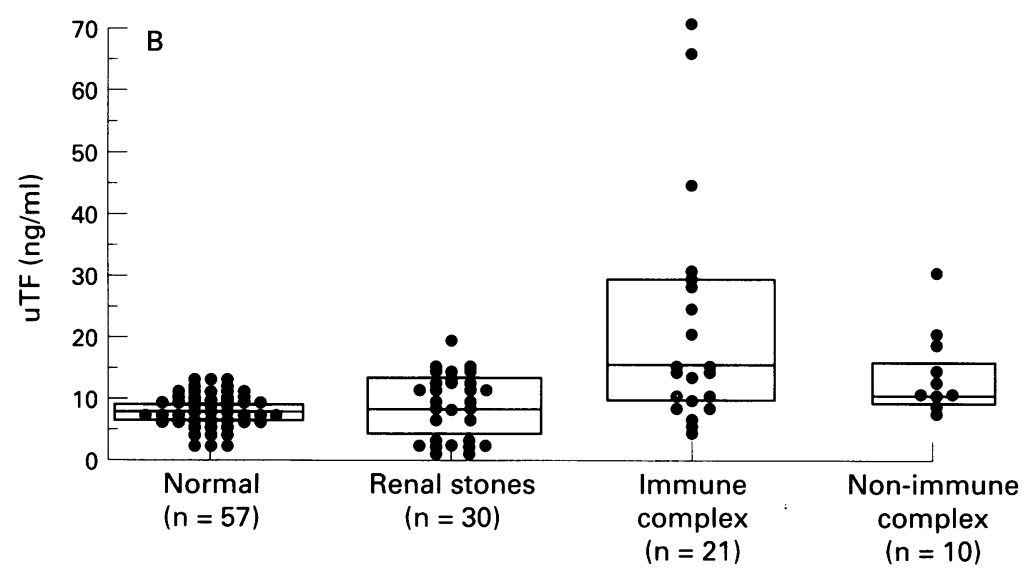

$\mathrm{PCl} \geqslant 0.2 \mathrm{mg} / \mathrm{mmol}$

Figure 2 Comparison of urinary tissue factor ( $U T F$ ) concentrations in controls and patients with immune complex (IC) glomerulonephritis and non-IC glomerulonephritis $(A, P C I<0.2 ; B, P C I \geq 0.2)$. Results are shown as median and interquartile ranges. $P C I$, protein creatinine index.
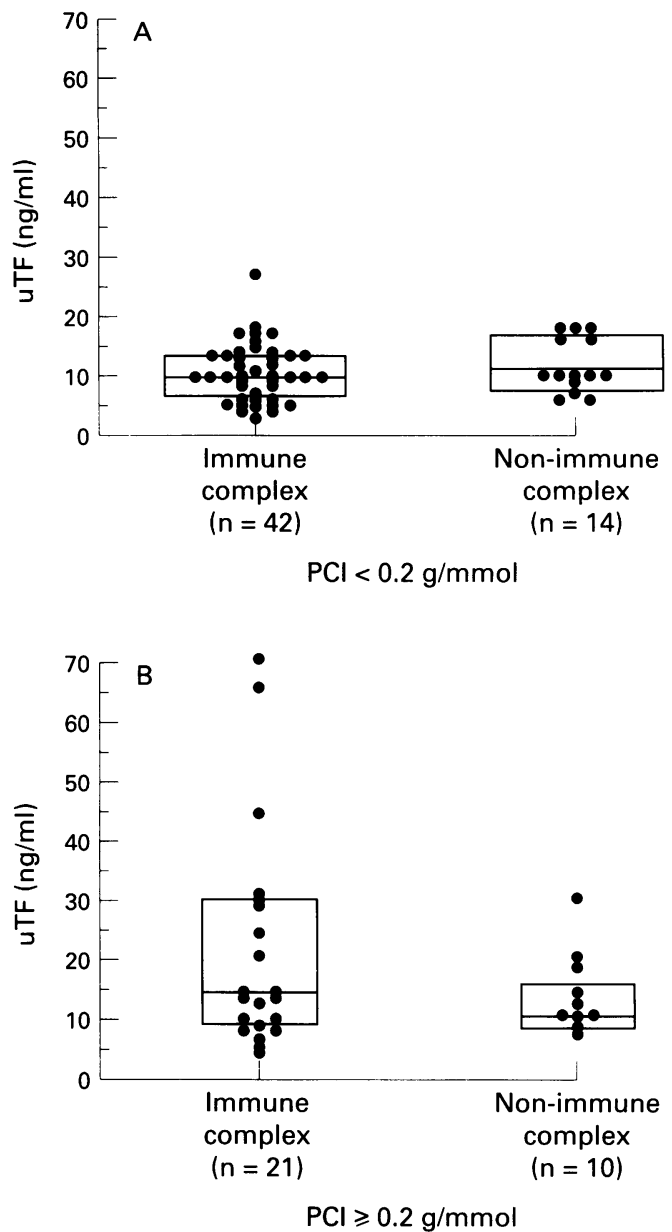

Figure 3 Comparison of urinary tissue factor $(u T F)$ concentrations in patients with immune complex (IC) glomerulonephritis and non-IC glomerulonephritis ( $A, P C I$ $<0.2 ; B, P C I \geq 0.2)$. Results are shown as median and interquartile ranges. PCI, protein creatinine index.

between the miscellaneous group and normal controls only $(p<0.05)$. With high PCI, there was a significant difference between the miscellaneous group and both the normal controls $(\mathrm{p}<0.01)$ and the renal stones group $(\mathrm{p}<0.05)$.

\section{Discussion}

The fact that several human and experimental models of glomerulonephritis show alterations in kidney tissue factor levels highlights the importance of this glycoprotein in glomerular pathology. Tissue factor, the normal route to coagulation activation, triggers glomerular fibrin deposition, ${ }^{16}$ which has been observed in many forms of clinical and experimental glomerulonephritis. ${ }^{60}$ Increased concentrations of tissue factor in glomerular diseases are found not only in the kidney itself, but also in the urine, where it is associated with lipid. ${ }^{28}$ Assessment of UTF in renal diseases has until now been mainly restricted to experimental models, with conflicting results. ${ }^{17}$ Thus urinary procoagulant activity in rabbits with nephrotoxic nephritis is reported to have disappeared during the onset of glomerulonephritis, ${ }^{41}$ while in a subsequent study using the same animal model a marked increase in the urinary procoagulant activity was observed during the development of glomerular injury. ${ }^{18}$ Recently, how- 
ever, the relation between the urinary procoagulant activity and fibrinolytic activity in human glomerulonephritis has been evaluated and a negative association found. ${ }^{17}$ The assay system employed in this latter study, however, may not have been completely reliable. In addition, the samples were dialysed, though uTF is bound to membrane microvesicles ${ }^{28}$ which provide the lipid for its functional activity. The structure and the orientation of these vesicles in relation to $\mathrm{UTF}$ is still poorly understood. This is important since the orientation of the lipid vesicles has been shown to affect the accessibility of tissue factor to factor VII/VIIa. ${ }^{42}$ Recently we have developed and validated a simple, clinically applicable kinetic chromogenic assay for measuring UTF activity which does not use dialysis (to be published).

The clinical applications of this new assay to patients with glomerulonephritis have not been explored before, although the assay has been successfully used to distinguish normal subjects from patients with malignant disease in the absence of inflammation. . $^{3-35}$

Using this assay system, uTF was found to be increased in patients with glomerulonephritis compared to normal controls and to patients with uncomplicated renal stones: $54.9 \%$ of the glomerulonephritis group had results above the upper quartile of the healthy control group, while only $36.7 \%$ of the renal stones group had abnormal values. Although the glomerulonephritis group had increased uTF concentrations, there was an overlap with the normal and renal stones groups (fig 1). This may have been due to the heterogeneity of the various groups, including the stage of evolution of the disease or treatment schedules (some patients were on treatment at the time of sample collection, though all patients on steroids were excluded from the study).

Although it could be argued that circulating tissue factor may enter the urinary filtrate in glomerulonephritis, tissue factor is constitutively expressed only by cells outside the vasculature, ${ }^{43}$ though its expression could be induced in endothelial cells and monocytes by endotoxin or cytokines. ${ }^{114}$ However, the procoagulant activity of blood monocytes in different forms of glomerulonephritis was not significantly different from that in a normal control group, ${ }^{17}$ neither were plasma tissue factor concentrations in patients with chronic glomerulonephritis. ${ }^{45}$

In our study, we found that uTF showed only a weak correlation with urinary protein excretion (expressed as protein creatinine index). We then divided the glomerulonephritis study groups into group I, with a PCI of $<0.2 \mathrm{~g} /$ $\mathrm{mmol}$, and group II, with PCI values $\geq 0.2 \mathrm{~g} /$ mmol. When the types of glomerulonephritis were divided into immune complex and non-immune complex subtypes, both groups showed a significant increase in the uTF concentrations compared with the controls, even when the PCI was only moderately raised. Although the immune complex subtypes in group II showed a wider range of UTF ( 8 to 29) compared with the non-immune complex group ( 7 to 16 ), the differences between the groups failed to reach statistical significance. The high levels of uTF observed in the immune complex subgroup could be related to various factors, including immunoglobulin and complement deposition, mononuclear cell infiltration, fibrin formation, and glomerular cell proliferation. This may cause direct or indirect activation of the resident glomerular cells or infiltrating inflammatory cells to express increased amounts of tissue factor. The presence of fibrin or fibrin related products acts as a macrophage aggregating agent $\mathrm{t}^{46-48}$ and stimulates glomerular mesangial cells directly through cytotoxic effects. ${ }^{49}$ In addition, changes in membrane structure cause tissue factor de-encryption which would result in enhanced tissue factor procoagulant activity. An obvious example of this is cell apoptosis, which has been shown to be associated with an increased cell surface tissue factor procoagulant activity. ${ }^{50}$ Whatever the mechanisms involved, this may lead to local activation of blood coagulation or of the fibrinolytic system. The extent of glomerular damage may therefore be reflected in the amount of uTF produced. This is supported by the finding of Wiggins et al, who showed, using an animal model, that procoagulant activity in rabbits with nephrotoxic nephritis not only increased in glomeruli but also appeared in urine during the progression of glomerular injury. ${ }^{18}$ This suggests that haemostatic alterations may represent changes of pathological importance in the development and progression of the diseases. However, in patients with diffuse glomerulonephritis we found no significant association between $\mathrm{UTF}$ activity and either tuft morphological changes or interstitial cell infiltration. The apparent lack of correlation found in this study could be a time factor, since the period between sample collection and biopsy exceeded three years in some cases. However, uTF may be a useful tool in assessing glomerular damage, particularly in immune complex glomerulonephritis, and perhaps in monitoring response to treatment. Further studies are required to evaluate its use as a marker of glomerular injury.

In conclusion, the $\mathrm{uTF}$ concentration is increased in patients with glomerulonephritis compared with controls, and is increased even when the protein creatinine index is only moderately raised. Our immune complex glomerulonephritis group showed wider ranges than the non-immune complex glomerulonephritis group and the results suggested that UTF production may be more important in immune complex glomerulonephritis. Further studies to evaluate $\mathrm{UTF}$ level in patients with glomerular abnormalities are required, especially to evaluate the influence of disease activity, stage, and the influence of treatment.

We thank Dr Rod Dathan and Dr Mary Rogerson, Consultan Physicians at Southampton University Hospitals for allowing u to study patients under their care. We thank Dr Mary Rogerson for commenting on the text. We also acknowledge the cooperation of Mrs Natasha Wilson, Renal Failure Monitoring Unit, for her help with the retrieval and collation of medical records.

1 Winter H, Majid NH. Glomerulonephritis-an emerging disease? Vet Bull 1984;54:327-35. 
2 Tipping PG, Dowling JP, Holdsworth SR. Glomerular procoagulant activity in human proliferative glomerulonephritis. $\mathcal{F}$ Clin Invest 1988;81:119-25.

3 Silva FG, Hoyer J, Pirani CL. Sequential studies of glomerular crescent formation in rats with antiglomerula basement membrane-induced glomerulonephritis and the role of coagulation factors. Lab Invest 1984;53:404-15.

4 Morita T, Suzuki Y, Chutg J. Structural and development of the glomerular crescent. Am $\mathcal{F}$ Pathol 1973;72:349-67.

5 Rondeau E, Nguyen G, Adida C, Peraldi M, Daniel Sraer A. Role de l'hemostase dans la formation de croissants au cours des glomerulonephrites extracapillaries. Nephrologie cours des glomer

6 Kincaid-Smith P. Coagulation and renal disease. Kidney Int 1972;2:183-90

7 Hancock W, Atkins R. Activation of coagulation pathways and fibrin deposition in human glomerulonephritis. Semin Nephrol 1985;5:69-77.

8 Ono T, Kanatsu K, Doi T, Sekita KI, Nagai H, Muso E, et al. Immunoelectron microscopic localization of fibrinrelated antigen in human glomerular diseases. Nephron 1989;52:238-43.

9 Takemura T, Yoshioka K, Akano N, Miyamoto H, Matsumoto K, Maki S. Glomerular deposition of crosslinked fibrin in human kidney diseases. Kidney Int 1987;32: 102-11.

10 Holdsworth SR, Tipping PG. Macrophage-induced glomerular fibrin deposition in experimental glomeruloneglomerular fibrin deposition in experimental glomer

11 Rivers RPA, Hathaway WE, Weston WL. The endotoxininduced coagulation activity of human monocytes. $\mathrm{Br} f$ Haematol 1975;30:311-16.

12 Muller AD, van Dam-Mieras MCE, Hemker HC. Measurement of macrophage cellular procoagulant activity. Haemostasis 1985;15:108-13.

13 Rickles FR, Levin J, Hardin JA, Barr CF, Conrad ME. Tissue factor generation by human mononuclear cells: effects of endotoxin and dissociation of tissue factor generation from the mitogenic response. F Lab Clin Med 1977;89:792803.

14 Edwards RL, Rickles FR, Cronlund M. Abnormalities of blood coagulation in patients with cancer. Mononuclear
cell tissue factor generation. $\mathcal{F}$ Lab Clin Med 1981;98:91728 .

15 Lwaleed BA, Francis JL, Chisholm M. Monocyte tissue factor level in benign and malignant disease [abstract]. $\mathrm{Br} f$ Haematol 1996;93:19.

16 Brentjens JR. Glomerular procoagulant activity and glomerulonephritis. Lab Invest 1987;57:107-11

17 Colucci M, Semeraro N, Montemurro P, Chiumarulo P Triggiani R, Morrone L, et al. Urinary procoagulant and fibrinolytic activity in human glomerulonephritis. Relationship with renal function. Kidney Int 1991;39:1213-17.

18 Wiggins RC, Glatfelter A, Brukman J. procoagulant activity in glomeruli and urine of rabbits with nephrotoxic nephritis. Lab Invest 1985;53:156-65.

19 Edwards RL, Rickles FR, Bobrove AM. Mononuclear cell tissue factor:cells of origin and requirements for activation. tissue factor:cells of origin
Blood 1979;54:359-70.

20 Tsao BP, Fair DS, Curtiss LK, Edington TS. Monocyte can be induced by lipopolysaccharide-triggered $\mathrm{T}$ lymphocytes to express functional factor VII/VIIa protease activity. $\mathcal{F}$ Exp Med 1984;159:1042-56.

21 Nemerson Y. The tissue factor pathway of blood coagulation. Semin Haematol 1992;29:170-6.

22 Hoyer JR, Michael AF, Hoyer LW. Immuno-fluorescent localization of antihemophilic factor antigen and fibrinogen in human renal disease. 7 Clin Invest 1974;53:1375-84.

23 Ardaillou R, Bens M, Edgington TS. Glomerular tissue factor stimulates thromboxane synthesis in human platelets via thrombin generation. Kidney Int 1992;41:361-8.

24 Bach RR, Nemerson Y, Konigsberg WK. Purification and characterization of bovine tissue factor. $\mathcal{F}$ Biol Chem 1981; 256:8324-31.

25 Guha A, Bach RR, Konigsberg W, Nemerson Y. Affinity purification of human tissue factor:interaction of factor VI and tissue factor in detergents micelles. Proc Natl Acad Sci USA 1986;83:299-302.

26 Nemerson Y, Bach R. Tissue factor revisited. Prog Hemost Thromb 1982;6:237-61.
27 Nemerson Y. The tissue factor pathway of blood coagulation. Semin Haemost 1992;29:170-6.

28 Wiggins R, Glatfelter A, Kshirsagar B, Beals T. Lipid vesicles and their association with procoagulant activity and glomeruli of rabbits with nephrotoxic nephritis. $L a b$ Invest 1987;56:264-72.

29 Carty N, Taylor I, Roath OS, El-Baruni K, Francis JL. Urinary tissue factor activity in malignancy. Thromb Res 1990 , 57:473-8.

30 Carty N, Taylor I, Roath OS, El-Baruni K, Francis JL. Urinary tissue factor activity in colorectal disease. $\mathrm{Br} \mathcal{F}$ Surg 1990;77:1091-4.

31 Adamson AS, Francis JL, Roath OS, Witherow RO'N, Snell ME. Urinary tissue factor levels in transitional cell carcinoma of the bladder. F Urol 1992;148:449-52.

32 Adamson AS, Francis JL, Witherow RO'N, Snell ME. Urinary tissue factor levels in prostatic carcinoma: A potential marker of metastatic spread. Br fUrol 1993;71:587-92.

33 Lwaleed BA, Karran SJ, Chisholm M, Francis JL. Urinary tissue factor in solid tumours. XXXI Congress of the European Society for Surgical Research 1996:49

34 Lwaleed BA, Francis JL, Chisholm M. Urinary tissue factor level in neoplastic diseases [abstract]. Br f Haematol 1996; 27:103.

35 Lwaleed BA, Chisholm M, Francis JL. Urinary tissue factor level in solid tumours. Br 7 Haematol 1996;93:18-19.

36 Churg J, Sobin LH. Renal diseases: classification and atlas of glomerular diseases. Tokyo: Igaku-Shoin, 1982

37 Carson SD, Konigsberg W.H. Cadmium increases tissue factor (coagulation factor III) activity by facilitating its reassociation with lipids. Science 1980;208:307-9.

38 Watanabe N, Kamei S, Ohkubo A, Yamanaka M, Ohsawa S, Makino $\mathrm{K}$, et al. Urinary protein as measured with a pyrogallo red-molybdate complex manually and in a Hitach 726 automated analyzer. Clin Chem 1986;32:1551-4.

39 Orsonneau J, Douet P, Massoubre C, Lustenberger P, Bernard S. An improved pyrogallol red-molybdate method of nard S. An improved pyrogallol red-molybdate method of 2233-6.

40 McCluskey RT, Vassalli P, Gallo G, Baldwin DS. An immunofluorescent study of pathogenic mechanisms in glomerular diseases. $N$ Engl f Med 1966;274:695-701.

41 Matsumura T, Hutt MP, Von Kaulla KN. Urinary procoagulant excretion in experimental renal disease. Proc Soc Exp Biol Med 1968;127:147-53.

42 Bach RR, Gentry R, Nemerson Y. Factor VII binding to tissue factor in reconstituted phospholipid vesicles: induction of cooperativity by phosphatidyl serine. Biochemistry 1986 ; 25:4007-20.

43 Drake T, Ruf W, Morrisey J, Edgington T. Functional tissue factor is entirely cell surface expressed on lipopolysaccharide-stimulated human monocytes and a constitutively tissue factor-producing neoplastic cell line. $f \mathrm{Cell}$ Biol 1989;109:389-95.

44 Moldow C, Bach R, Staskus K, Rick P. Induction of endothelial cell tissue factor by endotoxin and its precursors. Thromb Haemost 1993;70:702-6.

45 Koyama T, Nishida K, Ohdama S, Sawada M, Murakami $\mathrm{N}$, Hirosawa S, et al. Determination of plasma tissue factor antigen and its clinical significance. $\mathrm{Br} \quad \mathrm{f}$ Haematol 1994;87:343-7.

46 Holdsworth SR, Thomson NM, Glasgow EF, Atkins C. The effect of defibrination on macrophage participation in rabbit nephrotoxic nephritis: studies using glomerular culture and electron microscopy. Clin Exp Immunol 1979;37:3843.

47 Schreiner GF, Cotran RS, Pardo V, Unanue ER. A mononuclear cell component in experimental immunological glomerulonephritis. F Exp Med 1977;147:369-84.

48 Thomson NM, Holdsworth SR, Glasgow EF, Atkins RC. The macrophage in the development of experimental crescentic glomerulonephritis. Am ₹ Pathol 1979;94:223-34.

49 Tsumagari T, Tanaka K. Effects of fibrinogen degradation products on glomerular mesangial cells in culture. Kidney Int 1984;26:712-18.

50 Greeno EW, Bach RR, Moldow CF. Apoptosis is associated with increased cell surface tissue factor procoagulant activity. Lab Invest 1996;75:281-9. 